\title{
DETERMINATION OF ENDOPARASITES BY FAECAL EXAMINATION IN THE WILD BOAR POPULATION IN VOJVODINA (SERBIA)
}

\author{
Igor Stojanov ${ }^{1}$, Ivan Pavlović , Ivan Pušić ${ }^{1}$, Jasna Prodanov-Radulović1, \\ Radomir Ratajac ${ }^{1}$, Doroteja Marčić ${ }^{1}$, Božidar Savić ${ }^{2}$ \\ ${ }^{1}$ Scientific Veterinary Institute Novi Sad, Rumenački put 20, Novi Sad, Serbia \\ ${ }^{2}$ Scientific Veterinary Institute of Srbija, Vojvode Toze 14, Belgrade, Serbia
}

Received 22 June 2016; Received in revised form 1 August 2017; Accepted 13 September 2017

\begin{abstract}
The aim of our study was to determine whether and to what extent certain species of helminths and protozoa are present in the wild boar population living in hunting grounds in Vojvodina. For this purpose, 52 faecal samples of hunted wild boars (aged 6 months to 2 years) were examined. Examination of the faeces was performed using classical coproscopic laboratory methods. The following parasite species were identified: Metastrongylus spp. Ascaris suum, Trichuris suis, Physocephalus sexalatus, Strongyloides ransomi, Oesophagostomum sp. / Globocephalus sp., Hyostrongylus rubidus, Gnathostoma hispidum, Eimeria deblecki and Eimeria suis. The obtained results from this study indicated that wild boars are a potential reservoir of a variety of endoparasites, thus endangering the surrounding ecosystem.
\end{abstract}

Key words: wild boar, endoparasites, Vojvodina, faecal examination

\section{INTRODUCTION}

Wild animals are an integral part of the natural world. Continuous monitoring and control of wild animals is necessary in order to assess the extent of human impact on nature and, on the other hand, the impact of wild animals on the natural environment and humans. Fluctuations in population size of particular wild animal species often indicate an excessive interference by men in nature, which may be manifested by changes in the susceptibility to certain diseases $(15,19)$.

Within the European free-living wild animal population, the wild boar (Sus scrofa) deserves special attention as both an important part of hunting husbandry and as a distant ancestor of the domestic pig $(6,36)$. Wild boars are a potential

Corresponding author: Dr Ivan Pavlović, $\mathrm{PhD}$

E-mail address: dripavlovic58@gmail.com

Present address: Scientific Veterinary Institute of Srbija,

Vojvode Toze 14, Belgrade, Serbia

Phone/Fax: +381-11-2851096

Copyright: (C) 2017 Stojanov I. This is an open-access article published under the terms of the Creative Commons Attribution License which permits unrestricted use, distribution, and reproduction in any medium, provided the original author and source are credited.

Competing Interests: The authors have declared that no competing interests exist.

Available Online First: 2 December 2017

Published on: 15 March 2018

https://doi.org/10.1515/macvetrev-2017-0029 reservoir of a variety of bacterial, viral and parasitic diseases endangering the health of domestic swine, especially those grown in an extensive system, that is, on pasture $(22,26)$.

Presence of parasites and their impact on the health of wild boars in Serbia hunting areas has not yet been comprehensively investigated. We have only a limited number of papers published on this topic $(4,26,27,34,35)$. Because of the scarcity of such data in the literature, the present study was undertaken to evaluate helminths and protozoa species and their prevalence in hunted wild boars from nine hunting grounds in Vojvodina. Besides that, we would also like to find out if there is a difference in the presence and prevalence of types of parasites in relation to sex and age of hunting animals, as well as to animals hunting on open and closed hunting grounds.

\section{MATERIAL AND METHODS}

\section{Study area}

Vojvodina is situated in the northern part of Serbia.The region is divided by the Danube and Tisa rivers into: Bačka in the northwest, Banat 
Table 1. Examined hunting grounds and number of samples

\begin{tabular}{|c|c|c|c|}
\hline Name & Characteristic & Surface Area & No of sample \\
\hline Titel & $\begin{array}{l}\text { Encompassing hunting grounds nearby Tisza, Danube and Begej } \\
\text { rivers }\end{array}$ & 39637 ha & 12 \\
\hline Plavna (Bač) & $\begin{array}{l}\text { Lowland type hunting-ground with height between } 80 \text { and } 87 \\
\text { metres above sea level, hunting ground bordering the Danube fen }\end{array}$ & 2619 ha & 8 \\
\hline Koviljski rit & $\begin{array}{l}\text { Lowland type hunting-ground with height between } 78 \text { and } 84 \\
\text { metres above sea level. Greater part of it is under forests }\end{array}$ & 1955 ha & 6 \\
\hline Bosutske forest & Hunting ground bordering Bosutski rit & 12274 ha & 6 \\
\hline Kućine Sid & $\begin{array}{l}\text { Lowland type hunting-ground with height between } 79 \text { and } 80 \\
\text { metres above sea level. It is almost completely under forests }\end{array}$ & 1955 ha & 4 \\
\hline $\begin{array}{l}\text { Vranjak - Višnjićevo, } \\
\text { Sid }\end{array}$ & $\begin{array}{l}\text { Lowland type hunting-ground with height between } 79 \text { and } 80 \\
\text { metres above sea level }\end{array}$ & 12274 ha & 4 \\
\hline $\begin{array}{l}\text { Lower Danube } \\
\text { "Pancevo" }\end{array}$ & $\begin{array}{l}\text { Includes a large water surface of the Danube and marshy area } \\
\text { around Danube aits. }\end{array}$ & 3526.59 ha & 4 \\
\hline $\begin{array}{l}\text { Deliblato Sandpit, } \\
\text { Pancevo }\end{array}$ & $\begin{array}{l}\text { This is a lowland type hunting-ground with height between } 70 \text { and } \\
85 \text { metres above sea level and lies close to the Danube } \\
\text { (Dragićev hat are enclosed on } 1,850 \text { ha) }\end{array}$ & 31036.55 ha & 4 \\
\hline $\begin{array}{l}\text { Hrastovaca forests, } \\
\text { Subotica }\end{array}$ & $\begin{array}{l}\text { This is a lowland type hunting-ground with height ranging } \\
\text { between } 114 \text { and } 143 \text { metres above sea level. Enclosed part } \\
\text { comprises } 500 \text { ha of forests, } 35 \text { ha of pastures and meadows and } 8 \\
\text { ha of other vegetation }\end{array}$ & 4760 ha & 4 \\
\hline
\end{tabular}

in the east and Srem in the southwest. For testing purposes, we used wild boar faeces collected from 9 hunting grounds in Vojvodina during the autumn hunting season 2015. Samples originated from the following hunting grounds: from Bačka hunting grounds Titel, Hrastovača forest (Subotica) and Plavna (Bač), from Srem: Koviljski rit, Bosutske forest, Kućine-Šid, and Vranjak-Višnjićevo (Šid) and from Banat: Lower Danube "Pančevo" and Deliblato Sandpit, Pančevo. The data concerning the hunting grounds and the number of samples taken from them are shown in Table 1.

\section{Faecal sample collection and examination}

During the research period, we collected a total of 52 faeces samples from hunted wild boar. The animals that the samples were collected from were categorized according to the animals' age as a young (6 - 8 months) or an older group (over 8 months), while according to sex as female or male animals. After the evacuation, the samples from the various segments of the hose were collected and packaged in PVC bags that were marked on the outside. The following data were specified: sex and age of animals, hunting ground and date of hunting. All faecal samples were examined using a sedimentation and flotation method with saturated solution of $\mathrm{ZnSO}_{4}$ as previously described (10, 16, 31, 32).

We performed the determination of helminth eggs and protozoon oocysts based on morphometric characteristic using keys by Beugnet et al. (5), Euzeby (10), Kaufman (16), Kozlov (17) and Soulsby (32). Correct identification of Oesophagostomum sp. and Globocephalus urosubulatus with the coproscopic methods and without rearing larvae can be burdened with the possibility of too much error. For this reason we used eggs, whose morphology and biometrics allowed for classifying them as one of the two mentioned genera Oesophagostomum sp. / Globocephalus sp. In infected animals helminth eggs in per gram faecal sample (EPG) were determined by using the McMaster technique. Degrees of infection were assessed according to EPG and 50-200 eggs were was considered to be a low rate of infection, up to 300 was moderate and more than 300 was considered high.

The data obtained was analyzed using Chi-squere test $\left(\chi^{2}\right)$ to determine if the prevalence and intensity of infection depended on age, sex of examined wild boar and types of hunting grounds. In all analyses, the confidence level was held at $95 \%$.

\section{RESULTS}

A total of 52 faecal samples were examined. The results of the coproscopy revealed that 46 $(88.46 \%)$ wild boars harboured parasitic infections. According to the faecal examination, the following parasite species were identified: Metastrongylus sp., Strongyloides sp., Oesophagostomum sp./ Globocephalus sp., Hyostrongylus rubidus, Gnathostoma hispidum, Ascaris suum, Trichuris suis, Physocephalus sexalatus, Eimeria deblecki and Eimeria suis. The prevalence rates and EPG values of related parasite species were presented in Table 2. 
Table 2. Prevalence and EPG value of parasites in the investigated samples from 52 wild boars

\begin{tabular}{lccc}
\hline \multirow{2}{*}{ Parasites species } & \multicolumn{3}{c}{ Examined animals } \\
\cline { 2 - 4 } & infected & \% & EPG \\
\hline Metastrongylus spp. & 46 & 88.46 & 498 \\
\hline Ascaris suum & 16 & 30.76 & 3290 \\
\hline Trichuris suis & 11 & 21.15 & 165 \\
\hline Physocephalus sexalatus & 3 & 05.76 & 57 \\
\hline Strongyloides ransomi & 11 & 21.15 & 121 \\
\hline Oesophagostomum sp. / Globocephalus sp. & 16 & 30.76 & 479 \\
\hline Hyostrongylus rubidus & 7 & 13.46 & 110 \\
\hline Gnathostoma hispidum & 6 & 11.53 & 198 \\
\hline Eimeria deblecki & 11 & 21.15 & 192 \\
\hline Eimeria suis & 10 & 19.23 & 217 \\
\hline
\end{tabular}

In relation to the age of animals, our results suggested a higher prevalence of various parasite species in adult wild boars as compared to the younger ones. On the other hand, the extent of the infection was greater in younger than in adult wild boars, which is explained by the development of the immune response to certain parasitic species. In both age categories, Metastrongyloidea were the dominant parasites. The results of the coproscopic examination of wild boars in relation to age are presented in Table 3.
There was no significant age-related difference in the prevalence of parasite species. It was found that in younger animals the intensity of infection was lower than in older animals. However, statistically the intensity of infection did not significantly differbetween younger and older wild boars. Out of the total 46 infected wild boars, 16 (84.21\%) were young and $33(90.90 \%)$ were adult animals (Table 4).

Table 3. Intensity of infections in relation to the age of the wild boars

\begin{tabular}{|c|c|c|c|c|}
\hline \multirow{2}{*}{$\begin{array}{l}\text { Examined } \\
\text { group }\end{array}$} & \multirow{2}{*}{ Total } & \multicolumn{3}{|c|}{ Presence of parasites } \\
\hline & & Parasites species & infected & $\%$ \\
\hline \multirow{9}{*}{$\begin{array}{l}\text { Younger } \\
\text { (6-8 month) }\end{array}$} & \multirow{9}{*}{19} & Metastrongylus spp. & 16 & 84.21 \\
\hline & & Ascaris suum & 12 & 63.15 \\
\hline & & Trichuris suis & 4 & 21.05 \\
\hline & & Strongyloides ransomi & 6 & 31.57 \\
\hline & & Oesophagostomum sp. / Globocephalus sp. & 3 & 15.78 \\
\hline & & Hyostrongylus rubidus & 1 & 05.26 \\
\hline & & Gnathostoma hispidum & 2 & 10.52 \\
\hline & & Eimeria deblecki & 9 & 47.36 \\
\hline & & Eimeria suis & 7 & 36.84 \\
\hline \multirow{10}{*}{$\begin{array}{l}\text { Older } \\
\text { (>8 month) }\end{array}$} & \multirow{10}{*}{33} & Metastrongylus spp. & 30 & 90.90 \\
\hline & & Ascaris suum & 4 & 12.12 \\
\hline & & Trichuris suis & 7 & 21.21 \\
\hline & & Physocephalus sexalatus & 3 & 09.09 \\
\hline & & Strongyloides ransomi & 5 & 15.15 \\
\hline & & Oesophagostomum sp. / Globocephalus sp. & 7 & 21.21 \\
\hline & & Hyostrongylus rubidus & 6 & 18.18 \\
\hline & & Gnathostoma hispidum & 4 & 12.12 \\
\hline & & Eimeria deblecki & 2 & 06.06 \\
\hline & & Eimeria suis & 3 & 09.09 \\
\hline
\end{tabular}


Table 4. Intensity of infections in relation to the age of the wild boars

\begin{tabular}{|c|c|c|c|c|c|c|c|c|c|}
\hline \multirow{3}{*}{ Age } & \multirow{2}{*}{\multicolumn{3}{|c|}{ examined }} & \multicolumn{6}{|c|}{ Intensity of infection } \\
\hline & & & & \multicolumn{2}{|c|}{ Low } & \multicolumn{2}{|c|}{ Moderate } & \multicolumn{2}{|c|}{ High } \\
\hline & total & infected & $\%$ & no & $\%$ & no & $\%$ & no & $\%$ \\
\hline Young & 19 & 16 & 84.21 & 3 & 15.78 & 9 & 47.36 & 4 & 21.05 \\
\hline Adult & 33 & 30 & 90.90 & 7 & 21.21 & 20 & 60.60 & 3 & 09.09 \\
\hline
\end{tabular}

Table 5. Mixed infection in relation to the age of the wild boars

\begin{tabular}{|c|c|c|c|c|c|c|c|c|}
\hline \multirow[t]{2}{*}{ Age } & \multirow[t]{2}{*}{ examined } & \multicolumn{6}{|c|}{ Number of nematode species } & \multirow[t]{2}{*}{ Total } \\
\hline & & two & $\%$ & three & $\%$ & four & $\%$ & \\
\hline Young & 19 & 6 & 31.57 & 7 & 36.84 & 3 & 15.78 & 16 \\
\hline Adult & 33 & 4 & 12.12 & 14 & 42.42 & 2 & 06.06 & 20 \\
\hline
\end{tabular}

The results of the faecal examination revealed a greater number of parasite eggs in young wild boars than in adult animals.

Infection with only one nematode genus was found in 10 wild boars -4 young and 6 adult animals. Mixed infection was observed in 36 animals. In young animals, mixed infection occured in $84.21 \%$ $(16 / 19)$ and in $90.90 \%(20 / 33)$ of adult wild boars. Infection with two species was determined in 10 $(19.23 \%)$ faecal samples, with three species were 21 (40.38) faecal samples and with four species were 5 (09.61\%) faecal samples (Table 5). Adult animals were infected with more parasite species than the young and as such presented a potential source of infection and contaminants of hunting grounds.

Chi-square test analysis revealed that mixed infections did not significantly differ between younger and older wild boars.

The examination encompassed 30 male and 22 female samples originating from hunted animals. The results revealed no differences in the types of parasites with respect to the sex of the animals. Prevalence of infection was $95.45 \%$ in male animals $(21 / 22)$ and 83 $.33 \%(25 / 30)$ in female animals (Table 6).

Table 6. Prevalence of parasites according to sex of animals

\begin{tabular}{|c|c|c|c|c|}
\hline \multirow{2}{*}{$\begin{array}{l}\text { Examined } \\
\text { group }\end{array}$} & \multicolumn{4}{|l|}{ Presence of parasites } \\
\hline & Parasites species & examined & infected & $\%$ \\
\hline \multirow{10}{*}{ Female } & Metastrongylus spp. & 22 & 21 & 95.45 \\
\hline & Ascaris suum & 22 & 6 & 27.27 \\
\hline & Trichuris suis & 22 & 5 & 22.72 \\
\hline & Physocephalus sexalatus & 22 & 2 & 09.09 \\
\hline & Strongyloides ransomi & 22 & 6 & 27.27 \\
\hline & Oesophagostomum sp. / Globocephalus sp. & 22 & 7 & 31.81 \\
\hline & Hyostrongylus rubidus & 22 & 2 & 09.09 \\
\hline & Gnathostoma hispidum & 22 & 2 & 09.09 \\
\hline & Eimeria deblecki & 22 & 4 & 18.18 \\
\hline & Eimeria suis & 22 & 7 & 31.81 \\
\hline \multirow{11}{*}{ Male } & Metastrongylus spp. & 30 & 25 & 83.33 \\
\hline & Ascaris suum & 30 & 10 & 33.33 \\
\hline & Trichuris suis & 30 & 7 & 23.33 \\
\hline & Physocephalus sexalatus & 30 & 3 & 10.00 \\
\hline & Strongyloides ransomi & 30 & 5 & 16.66 \\
\hline & Oesophagostomum sp. / Globocephalus sp. & 30 & 10 & 23.33 \\
\hline & Hyostrongylus rubidus & 30 & 5 & 16.66 \\
\hline & Gnathostoma hispidum & 30 & 4 & 13.33 \\
\hline & Echinococcus granulosus (larvae) & 30 & 6 & 20.00 \\
\hline & Eimeria deblecki & 30 & 7 & 23.33 \\
\hline & Eimeria suis & 30 & 3 & 10.00 \\
\hline
\end{tabular}


Table 7. Intensity of infection with parasites in relation to the sex of the wild boars

\begin{tabular}{|c|c|c|c|c|c|c|c|c|c|}
\hline \multirow{3}{*}{ Sex } & \multirow{2}{*}{\multicolumn{3}{|c|}{ examined }} & \multicolumn{6}{|c|}{ Intensity of infection } \\
\hline & & & & \multicolumn{2}{|c|}{ Low } & \multicolumn{2}{|c|}{ Moderate } & \multicolumn{2}{|c|}{ High } \\
\hline & total & infected & $\%$ & no & $\%$ & no & $\%$ & no & $\%$ \\
\hline Male & 22 & 21 & 95.45 & 4 & 18.18 & 15 & 63.63 & 2 & 09.09 \\
\hline Female & 30 & 25 & 83.33 & 4 & 01.33 & 14 & 46.66 & 7 & 23.33 \\
\hline
\end{tabular}

Table 8. Mixed infections in relation to the sex of the wild boars

\begin{tabular}{ccccccccc}
\hline \multirow{2}{*}{ Sex } & \multirow{2}{*}{ examined } & \multicolumn{3}{c}{ number of nematode genus } & \multicolumn{2}{c}{ Total } \\
\cline { 3 - 10 } & & two & $\%$ & three & $\%$ & four & $\%$ & \\
\hline Male & 22 & 4 & 18.18 & 4 & 18.18 & 7 & 31.88 & 15 \\
\hline Female & 30 & 9 & 30.00 & 11 & 36.66 & 1 & 03.33 & 21 \\
\hline
\end{tabular}

Intensity of infection according to the sex of animals is presented in Table 7.

There was no evidence for sex-related differences in the prevalence and intensity of parasite species.

Infection with only one nematode genus was found in 4 female and 6 male animals. Meanwhile, mixed infections were observed in 36 animals. In female animals mixed infections occured in $68 / 61 \%$ $(15 / 22)$ and in male wild boars the number was $70.00 \%(21 / 30)$ (Table 8$)$.

The statistical analysis showed that the sex of wild boars had an influence on infection with four parasite species $\mathrm{P}<0.05$. Intensity of mixed infections did not significantly differ with regards to infection with two and three parasites species.

\section{DISCUSION}

During our examination, the most abundant parasite species was Metastongylus sp. A high percentage of Metastongylus species found in wild boars was reported in France (13), Germany (18), Spain (8) and Poland (28, 29). Lungworms also usually occurred outside the European continent, such as in Turkey $(30)$, Iran $(9,31)$ and China (37). These findings indicate a wide global distribution of transient hosts for these parasites - Earthworm (,rain worm“) genera Eisenia, Allolobophora, Dendrobaena, Lumbricus, Octolasium or Heledrillus, which are commonly part of the diet of wild pigs (23). Research performed in several regions of Serbia - Belgrade, Branicevski and Severnobacki (4, 26, 34, 35) demonstrated a high prevalence of Metastrongylus infection in wild boars, though the prevalence of particular species varied from area to area. These findings concerning the Metastrongylus species is similar to our result $(88.46 \%$ of processed material). Metastrongylus pudendotectus was the dominant species in the northern areas of Serbia, whereas M.apri dominated in the south. Similar findings were recorded in domestic pigs in organic production (23).

The European research on wild boar helminths resulted in a list of 30 species, encompassing flukes, tapeworms, nematodes, and acanthocephalans, as well as their larvae. Examinations performed in Germany (2, 3, 18), France (13), Hungary (35) and in Czech Republic and Slovakia $(1,21)$ indicated that the helminth and protozoa species which we found usually occurred in wild boars in Europe. The importance of testing wild boars for the presence of endoparasites has been gaining increasing attention taking into account the importance of parasites for domestic pigs and the losses and damage they can cause, as well as the problems related to management and its effects on pig production. According to the reports of several authors $(19,22,30,37)$, it is apparent that the parasitic fauna of domestic pigs is identical with the corresponding fauna of wild boars. These findings suggest that there is a possibility of mutual transmission of parasites between the two groups of animals, which largely depends on the production and husbandry system. Some authors $(1,19,23$, 25) reported that the presence of parasites affects the production of pigs and that pigs raised in an open system or an extensive production system are potential reservoirs of various parasitic pathogens that continuously circulate in the particular area of natural environment of pigs. This statement is supported by the global presence of some parasitic 
species such as Ascaris suum, Trichuris suis, Oesophagostomum spp, Metastromngylus spp. or Macracanthorhynchus hirudinaceus (23, 24, 25). Similar problems occur in organic pig production, which does not implicate the application of preventive anthelmintic drugs (26).

Problems related to the presence of parasites in wild pigs are very similar with problems related to parasitosis in swine production. Consequently, continuous monitoring and control of wild boar population is highly important for this sector of animal husbandry.

The problem with the parasitic fauna of wild pigs in relation to their habitats has been present in several studies. Jarvis et al. (14) reported on testing of wild boar for the presence of parasites in an isolated territory in Estonia, i.e. on an island. Popiołek et al. (29) examined the influence of natural and breeding conditions of helminths of wild boar (Sus scrofa L.) in Lubin Forest (Poland). The presence of seven species of helminths was established, including several Metastrongylus species, Ascaris suum, Trichuris suis, Dicrocelium dendricum and larvae of Tenia hydatigena. The most prevalent finding was the presence of lung nematodes ( $82 \%$ of examined animals). Similar results were obtained by comparing the findings of parasites in pigs held in free hold and wild boar in the same areas $(26,34,35)$.

Jarvis et al. (14) noticed that natural barriers, that is, sufficient distance of the island from the mainland, prevented the transmission of other types of parasites, thus the spectrum of parasites on the island was lesser than the parasitic fauna of wild pigs on the mainland. This natural barrier particularly affects biohelminths, whose intermediate hosts are not globally distributed, yet depend on the type of habitat and its ecological valence (prevalence of dry or moist habitats, microclimate, flora and fauna of the habitat, the impact of biotic factors, etc.). During our examination at various hunting grounds in Vojvodina, we concluded that there was no fundamental difference in the fauna of the parasite, though there were natural barriers like rivers in some hunting grounds.

The importance of territorial isolation of the wild boars and its relation to the parasitic fauna was addressed in the study of Fernandez-de-Mera et al. (11). The authors investigated the presence of parasites in the wild boar population in central Spain and compared it with findings in the same animal species in France, which were intended for import. The obtained results confirmed that the movement of animals would pose an increased risk because of significant differences in the number and species of identified parasites in animals from different regions. In imported wild boars, different parasitic species (Oesophagostomum dentatum, Ascaris suum and Trichuris suis) were identified, which had not existed in central Spain. Similar observations were reported in Poland, where the types and prevalence of helminths in wild boars in the northwestern region of Poland (21) were different from the findings in central Poland (7). Such findings correspond with the results reported in Serbia, where helminth fauna in wild boars significantly differed between the hunting grounds in North Backa, Braničevo (South Serbia) and Belgrade area (Central Serbia) (4, 26, 27, 34).

Examination of the presence of parasites with regard to animals' gender did not reveal any differences in parasitic fauna between female and male animals (Table 3). Our results are thus consistent with the reports of other authors (2, 3, 12, 14, 18).

\section{CONCLUSION}

Our research revealed the presence of parasitic fauna in wild boar (Sus scrofa) population in the nine investigated hunting grounds. The detection of the same parasites species in different hunting grounds, which are separated with rivers, canals and hills, is very important. Because of that, we may conclude that natural barriers do not prevent the spread of parasitic fauna in the examined regions (Vojvodina). Our results indicate that parasites are uniformly expanded in all examined groups.

Damagesassociatedwith the presenceofparasites in wild animals are difficult to estimate. This problem requires a systematic and continuous approach in the future. Damages resulting from reduced weight, lower fertility rates, burdening of the immune system and increased susceptibility to other infectious diseases can be assessed directly or indirectly. In that respect, development of an appropriate methodology adjusted to our conditions is necessary for determining the actual damage in this segment of the ecosystem and improving the wildlife welfare.

\section{CONFLICT OF INTEREST}

The authors declared that they have no potential conflict of interest with respect to the authorship and/or publication of this article. 


\section{ACKNOWLEDGEMENT}

This investigation was financially supported by the Ministry of Education, Science and Technological Development, Republic of Serbia, Project No. TR 31084.

\section{REFERENCES}

1. Antolová, D., Reiterová, K., Dubinský, P. (2006). The role of wild boars (Sus scrofa) in circulation of trichinellosis, toxocarosis and ascariosis in the Slovak Republic. Helminthol. 43(2): 92 - 97. https://doi.org/10.2478/s11687-006-0018-9

2. Barutzki, D., Schoierer, R., Gothe, R. (1990). Helminth infections in wild boars in enclosures in southern Germany: species spectrum and infection frequency. Tierärzt.Prax. 18(5): 529-534.

3. Barutzki, D., Schoierer, R., Gothe, R. (1991). Helminth infections in wild boars kept in enclosures in southern Germany: severity of infections and fecal intensity. Tierärzt. Prax. 19(6): 644-648.

4. Bečkei, Ž., Molnar, T., Seleš, A., Pavlović, I., Pavlićević, N., Rudinski, P., Kiškarolj, F. (2011). The parasitic fauna of wild boars from the territory of the North Bačka district. Abstracts and short contents of the 22nd Vegetarian conference of Serbia. September 14-17, (pp. 226-227), Zlatibor, Serbia

5. Beugnet, F., Polak, B., Dang, H. (2008). Atlas of coproscopy (pp. 229-255). Paris: Kalianxsis Publishing.

6. Corwin, R.M., Stewart, T.B. (1999). Internal parasites. In: B.E. Straw, S. D'Allaire, W.L. Mengeling, D.J. Taylor (Eds.), Diseases of swine (pp.713-730). 8th edition. Ames: Iowa State University Press.

7. Drozdz, J., Zalewska-Schonthaler, N. (1987). Metastrongylus confusus, a lungworm of wild boars, new for Poland. Wiadom. Parazytol. 33, 217218.

PMid:3687017

8. De-la Muela, N., Hernandez-de-Luja, S., Ferre, I. (2001). Helminths of wild boar in Spain. J. Wild. Dis. $37,840-843$. https://doi.org/10.7589/0090-3558-37.4.840 PMid:11763752

9. Eslami, A, Farsad-Hamdi, S. (1992). Helminth parasites of wild boar, Sus scrofa, in Iran. J. Wild. Dis. $28(2)$ : $316-318$.

https://doi.org/10.7589/0090-3558-28.2.316

PMid:1602589
10. Euzeby, J. (1981). Diagnostic experimental des helminthoses animales. Tome 1. (pp.183-194). Paris: ITVS Publishing.

11. Fernandez-de-Mera, G. I, Gortazar, C, Vicente, J., Höfle, U., Fierro, Y. (2003). Wild boar helminths: risks in animal translocations. Vet. Parasitol. 115, 335-341. https://doi.org/10.1016/S0304-4017(03)00211-5

12. Hälli, O., Ala-Kurikka, E., Peltoniemi, O., Heinonen, M. (2010). The prevalence of internal parasites in wild boar farms in Finland. Acta Vet. Scandinavica 52 (Suppl 1): S29.

https://doi.org/10.1186/1751-0147-52-S1-S29

PMCid:PMC2994306

13. Humbert, J.F., Henry, C. (1989). Studies on the prevalence and the transmission of lung and stomach nematodes of the wild boar (Sus scrofa) in France. J. Wild. Dis. 25, 335-341.

https://doi.org/10.7589/0090-3558-25.3.335

PMid:2788229

14. Jarvis, T., Kapel, CH., Moks, E., Talvik, H., Magi, E. (2007). Helminths of wild boar in the isolated population close to the northern border of its habitat area. Vet. Parasitol. 150, 366-369.

https://doi.org/10.1016/j.vetpar.2007.09.015

PMid:17964726

15. Jovanović V., Orlić, D. (2003). Infectious and parasitic diseases of humans and animals. In: D. Popović (Eds.), Man and nature (pp. 281-284). Novi Sad: Matica Srpska.

16. Kaufman, J. (2001). Parasitic infection of domestic animals. A diagnostic manual (pp. 291-336). BaselBoston-Berlin: Birkhauser Verlag. PMid:11495850

17. Kozlov, D.P. (1977). Intestinal helminths of mammalian in USSR. Academy of Science SSSR, Moskva.

18. Mennerich-Bunge, B., Pohlmeyer, K., Stoye, M. (1993). The helminth fauna of wild boars of the west Berlin forests. Berliner und Münchener tierärztliche Wochensch J. 106 (6): 203-207.

19. Naglić, T., Hajsig, D. (1993). Veterinary Immunology (pp. 126-128). Zagreb: Školska knjiga

20. Nansen, P., Roepstorff, A. (1999). Parasitic helminths of the pig: factors influencing transmission and infection levels. Int. J. Parasitol. 29, 877-891. https://doi.org/10.1016/S0020-7519(99)00048-X

21. Nosal, P., Kowal, J., Nowosad, B. (2010). Structure of Metastrongylidae in wild boars from southern Poland. Helminthol. 47(4): 212 - 218. https://doi.org/10.2478/s11687-010-0033-8 
22. Páv, J., Kotrlý, A., Zajǐček, D. (1963). Remarks on helminths parasitizing in wild boars (Sus scrofa L.) in reservations and ordinary forests. Lesnic. Časopis $36,251-260$.

23. Pavlović, I., Hudina, V., Pupavac, S., Stevanović, Đ., Kulišić, Z., Stevanović S. (2005). Metastrongylidosis of swine. Proceedings of the PKB Agroekonomik Institute 11(3-4): 133-141.

24. Pavlović, I., Hudina, V., Ivetić, V., Savić, B., Kulišić, Z., Đukić, B. (2007). Makrakantarhinhosis of swine. Proceedings of the PKB Agroekonomik Institute 13(3-4): 101-105.

25. Pavlović, I., Hudina, V., Savić, B, Ivetić, V., Kulišić, Z., Jakić-Dimić, D., Minić, J., Minić, S. (2008). Verminous swine gastritis. Proceedings of the PKB Agroekonomik Institute 14(3-4): 109-117.

26. Pavlović, I., Đorđević, M., Kulišić, Z., Savić, B., Hadžić, I. (2011). Parasitic fauna of wild boars from hunting areas of Belgrade. Abstracts and short contents of the 22nd Vegetarian Conference of Serbia, September 14-17, (pp. 224-225), Zlatibor, Serbia

27. Petrović, Z., Borđoški, A., Popović, S. (1966). Contribution to the fauna of parasites in wild boar. Osjek: NIP Štampa.

28. Pilarczyk, B., Balicka-Ramisz, A., Cisek, A., Szalewska, K., Lachowska, S. (2004). Prevalence of Eimeria and intestinal nematodes in wild boar in north-west Poland. Wiadom. Parazytol. 50(3): 637640.

PMid:16865979

29. Popiołek, M., Knecht, D., Szczęsna-Staśkiewicz, J., Czerwińska-Rożałow, A. (2010). Helminths of wild boar (Sus scrofa L.) in natural and breeding conditions. Bull. Vet. Instit. Pulawy 54, 161-166.

30. Senlik, B., Cirak, V.Y., Girisgin, O., Akyol, C.V. (2011). Helminth infections of wild boars (Sus scrofa) in the Bursa province of Turkey. J. Helminthol. 85(4): 404-408. https://doi.org/10.1017/S0022149X1000074X PMid:21114894
31. Solaymani-Mohammadi, S., MobedI, I., Rezaian, M., Massoud, J., Mohebali, M., Hooshyar, H., Ashrafi, K., Rokni, M.B. (2003). Helminth parasites of the wild boar, Sus scrofa, in Luristan province, western Iran and their public health significance. J. Helminthol. 77(3): 263-267.

https://doi.org/10.1079/JOH2003168

PMid:12895286

32. Soulsby, E.J.L. (1977). Helminths, arthropods and protozoa of domesticated animals. London: Baillier, Tindall and Cassell Pub.

PMCid:PMC1445497

33. Šibalić, S., Cvetković, Lj. (1980). Diagnostic of parasitic diseases of domesticated animals (pp. 6089). Beograd:OZID.

34. Stokić-Nikolić, S., Dobrosavljević, I., Đurić, B., Pavlović, I. (2011). Parasitic fauna of wild boars from the Branicevo district. Abstracts and short contents of the 22nd Vegetarian Conference of Serbia, September 14-17, (pp. 220-223), Zlatibor, Serbia

35. Stokić Nikolić, S., Živojinović, M., Lazić, M., Pavlović, I., Balbotinović Spasić, D., Rogožarski, D. (2015). Endoparasitosis of wild boar in the epizootiological region of VSI "Pozarevac". Abstracts of XVII Symposium of Epidemiologists and Epidemiologists (XVII Epizootiological Days), April 23-24, (pp. 127-128), Niš, Serbia PMid:25603541

36. Takacs, A. (1997). Contribution to the helminth infestation in wild boar (Sus scrofa L.) in Hungary. Wiener Tierärzt. Monatsschr. 84, 314-316.

37. Weng, B.Y., Hu, Y.J., Li, Y., Li, B.S., Lin, R.Q., Xie, D.H., Gasser, R.B., Zhu, X.Q. (2005). Survey of intestinal parasites in pigs from intensive farms in Guangdong Province, People's Republic of China. Vet. Parasitol. 127, 333-336. https://doi.org/10.1016/j.vetpar.2004.09.030 PMid:15710534 